\title{
THE LIMITS OF INDUSTRIALIZATION IN POST-ORDE BARU INDONESIA: State-Corporatism and Technological Inferiority
}

\author{
Defbry Margiansyah \\ Global Studies Programme \\ Albert-Ludwigs-Universität Freiburg, Germany \\ Email:defbry@gmail.com/defbry@yahoo.com
}

\begin{abstract}
As competitiveness gains currency, it compels many governments' concerns in achieving economic resilience to avoid the Middle-income Trap. Indonesia has focused on promoting industrialization and economic diversification as a response to the probability of being trapped. However, it has been shown that the performance of the manufacturing sector in Indonesia has been unsatisfying due to the inability to enhance human and technological competences and managing the transition from labor- and resource-intensive to capital- and technology-intensive industries. This situation signifies the importance of industrial revitalization in Indonesia by strengthening the weakest links, innovation, and human capital through the adoption of capability-focused industrial policy on innovation and technology. This paper examines factors that challenge Indonesia to develop innovation and technological capabilities in the industrial sector and analyze the role of the state in organizing industrial policy based on the adoption of the capabilities-focused strategy within reindustrialization in the democratic setting. Employing Thee Kian Wie's conditions for industrial technology development and Dani Rodrik's industrial policy, this study reveals vital factors challenging Indonesia's efforts on innovation and technological development in manufacturing industries. It also found two ideational factors that affect the Orde-Baru bureaucratic culture and practice remain intact in the policy formulation and implementation, and ultimately obstructing current industrial policy to achieve the policy goals and right institutional setting.
\end{abstract}

Keywords: political economy, democratic governance, industrialization, industrial policy, innovation, technological development

\begin{abstract}
Abstrak
Gagasan akan daya saing semakin mendorong perhatian banyak pemerintah dalam mencapai ketahanan ekonomi untuk menghindari Perangkap berpenghasilan Menengah. Indonesia telah berfokus untuk mempromosikan industrialisasi dan diversifikasi ekonomi sebagai respons terhadap kemungkinan terperangkap. Namun, telah ditunjukkan bahwa kinerja sektor manufaktur di Indonesia tidak memuaskan karena ketidakmampuan meningkatkan kompetensi manusia dan teknologi dan mengelola transisi dari industri padat karya dan sumber daya ke industri padat modal dan teknologi. Situasi ini menandakan pentingnya revitalisasi industri di Indonesia dengan memperkuat mata rantai, inovasi, dan sumber daya manusia yang paling lemah melalui penerapan kebijakan industri yang berfokus pada kemampuan dalam inovasi dan teknologi. Makalah ini membahas faktor-faktor yang menantang Indonesia untuk mengembangkan inovasi dan kapabilitas teknologi di sektor industri dan menganalisis
\end{abstract}


peran negara dalam mengatur kebijakan industri berdasarkan adopsi strategi yang berfokus pada kapabilitas dalam reindustrialisasi dalam lingkungan demokratis. Dengan menggunakan kondisi Thee Kian Wie untuk pengembangan teknologi industri dan kebijakan industri Dani Rodrik, penelitian ini mengungkapkan faktor-faktor kunci yang menantang upaya Indonesia dalam inovasi dan pengembangan teknologi di industri manufaktur dan menemukan dua faktor ideasional yang menghambat kebijakan industri saat ini gagal mencapai tujuan kebijakan dan pengaturan kelembagaan yang tepat.

Kata Kunci: ekonomi politik, pemerintahan demokratis, industrialisasi, kebijakan industri, inovasi, pengembangan teknologi,

\section{INTRODUCTION}

Competitiveness has recently become an urgent matter to many decision-makers and governments in enhancing and sustaining their economic resilience in the global economy for avoiding the so-called "middle-income trap" (Cann, 20I6). The notion of "the trap" refers to a condition under which developing economies experienced growth slowdown once achieved middle-income status. Then, those countries have difficulties to be higher income due to their inability competing others with either higher value-added activities or lower minimum wages globally (Felipe, Ustav, \& Galope, 20I4; Im \& Rosenblatt, 2013).

According to Eichengreen, Park, \& Shin (2013), the most robust determinants of preventing a slowdown are high-quality human capital and high-tech exports in which highly skilled labors would provide the required capacities to promote the technology ladder out of lowvalue-added and unskilled-labor intensive sectors. The proposition above demonstrates how technological capability and upgraded human resources in improving value-added industries and manufactured exports are perceived as significant forces in economic growth. Accelerating industrialization, based on those two, is crucial for many developing countries to circumvent declining competitiveness and eventually to avoid the growth slowdown in the context of a globally competitive economy.

Indonesia has concerned about promoting industrialization and economic diversification as responses to the trap. It is clearly defined in Law No. 27 on Long-Term National Development Plan (RPJPN) from 2005 to 2025. Speeding up industrialization is an urgent matter for
Indonesia as its industrial sector has been negatively affected by the Asian Financial Crisis (AFC). The post-crisis industrial growth has fallen below the economy-wide average resulting in the declining and less competitive manufacturing sector that sparked fears of premature deindustrialization. Despite inclining to decline slightly, manufacturing remains a potential sector to be developed as an engine of growth comparing to other sectors like agriculture, oil and gas, and mining. In so doing, the government of Indonesia has intervened specific activities, industries, and sectors deemed beneficial for the long-term economy through introducing a set of industrial policy since 2008 to boost rapid and sustainable economic growth (Aswicahyono, Hill, \& Narjoko, 20I2; Tijaja \& Faisal, 20I4). The industrial sector in this paper refers to manufacturing industries specifically, not included extractive industries.

However, according to the recent World Bank Open Data, the performance of the manufacturing sector in Indonesia has been unsatisfying. It can be assessed from several indicators as follow. First, the contribution of manufacturing value-added to Indonesia's Gross Domestic Product (GDP) tends to decline from 2002 to 2016 gradually, which were from 3I,9 percent to 20,5 percent. Second, the share of net exports constituted I9, o percent of GDP in 2016. This number was a significant fall, comparing the post-crisis peak in 2000 with 40,9 percent. Third, the contribution of high-technology exports to manufactured exports remains very low in which the portion continuously dropped at 5,7 percent in 2016 from 16,5 percent in 2005. Fourth, the percentage of Indonesia's manufactures exports to merchandise exports 
in 2016 has shown a definite increase at 47,6 percent from 34,I percent in 201 . The 2016 rate was at the bottom of the list in comparison to other middle-income countries like Malaysia, Thailand, India, and China (World Bank, 20I7d, 20I7a, 20I7b, 20I7c).

The facts have demonstrated how Indonesia failed to compete with the manufacturing sector of other emerging economies is in the unconvincing condition as the motor of growth. More critically, Indonesia's export structure remains unable to manage the transition from labor- and resource-intensive to capital- and technology-intensive industries, and eventually to the transformation to high-tech-based growth. It indicates that the economic performance of the country is not only vulnerable to external shocks but also likely to be stuck in the middle-income country (Basri \& Putra, 20I6). As a consequence, the effectiveness of Indonesia's industrial policy implementation is questioned.

This situation signifies the importance of industrial revitalization in Indonesia by strengthening the weakest links, innovation, and human capital (Tijaja \& Faisal, 20I4). Besides ensuring that supply-side investment, open policies, and regulatory reform (Aswicahyono et al., 20I2), focusing on innovation and human capital as the basis of industrial revitalization is essential agenda for the government to prompt re-industrialization effort as a way of avoiding growth slowdown. The lack of national innovation development is at the core of the slowdown trap, which is subsequently represented by low productivity growth.

Taking into account, Indonesia needs to learn from the 30 years' failed experience of Latin American countries in escaping the Middle-Income Trap, as Eva Paus (20I7) studied. She argues that the primary failure of Latin American experience was the adoption of market-led industrialization as a model changing from state-led strategy in accelerating industrial development. For example, heavy reliance on market forces, the pursuit of greater integration into Global Value Chains (GVCs), excessively encouraging foreign direct investment (FDI), and the most critical thing, disregarding the development of domestic innovation capabilities. This experience suggested that middle-income countries are required to adopt a capability-focused strategy focusing on developing innovation, moving up the technology ladder, creating decent jobs, and ultimately advancing high-quality human capital. Also, this strategy has an emphasis on political will and commitment to commence and implement a technology-driven innovation strategy in industrial policy. Hence, it implies that analyzing the dynamic of an institution is required.

To that end, industrial policy should not conceptually be defined as old-style selective intervention emphasis on protectionist measures (Chang \& Andreoni, 20I6), but "as much about eliciting information from the private sector on significant externalities and their remedies as it is about implementing appropriate policies" as Dani Rodrik suggested (2004). This definition acknowledges the process of building public-private strategic collaboration that has mutual interests in uncovering where the most significant obstacles to industrial performance lie and what type of interventions are the most likely to remove them. Industrial policy should focus on the process of getting policy and institutional setting right. It includes strategies to create favorable condition for changing the environment and ensuring democratically accountable, transparent, and legitimate upheld in the policy implementation with complete monitoring and controlling mechanisms, rather than on the policy outcomes within ex-ante reasoning.

Regarding policy implementation, isolating the private sector is not only undesirable but also irrelevant for the $2 \mathrm{I}^{\text {st }}$ industrial policy. The state must attempt to provide fair and inclusive interest representation in enabling public-private collaboration, self-discovery process, innovation and entrepreneurship, and process-oriented policy in order to absorb the stakeholders' demand and information optimally. Meanwhile, it must assure to generate the right institutional settings in protecting the industrial policy from illegitimate and corrupt practices involving dishonest 
bureaucrats and crooked businesspeople. This proposition subsequently stresses the crucial role that political elites and interest groups (big corporations and foreign network firms) play in justifying strategic goals of industrial policy and interests of development based on their interpretation rather than objective consideration on the ideal policy (Rodrik, 2004). In analyzing interest representation of the non-state or private actors in industrial policy, this paper employs Cohen and Uphoff's (I980) four modes of participation comprising "participation in decision-making," "participation in implementation," "participation in benefits," and "participation in evaluation." Hence, these typologies of participation enable us to identify the approaches used in industrial policy, whether it is top-down or bottom-up approaches, and analyze the consequences of the approach used in the policy.

Based on the problems and analytical framework explicated above, this paper examines factors hindered Indonesia from developing innovation and technological capabilities in the industrial sector. It also analyzes the role of the state in organizing industrial policy based on the adoption of the capabilities-focused strategy within re-industrialization in democratic Indonesia. The purpose of this paper is to provide a broad picture of the challenges of innovation and technological upgrading in Indonesia's re-industrialization effort and to present other perspectives on the government's role in both formulation and implementation of industrial policy. Whether it was treated as a means of increasing technological development for industries in Indonesia or not, rather than give an insight on economic of scale or market imperfection that many economists discuss. Moreover, the study only covers the 2004-20I4 period of the era, given a relatively long-time frame of re-industrialization in post-Orde Baru Indonesia.

\section{THE CURRENT STATE OF}

\section{INNOVATION IN INDONESIA}

In general, the status of innovation capacity in post-Orde Baru Indonesia was weak, a critical condition for a country identified as one of the world's fastest economies. The assessment has been shown in total scores in the Global Innovation Index (GII) from 20II to 2017. The figure I.I below exhibits that Indonesia's innovative capacity is stagnant and lagging behind the significant ASEAN economies like Singapore, Malaysia, Thailand, and the Philippines, while performing slightly better than the region's low middle-income country, Cambodia. This poor performance of innovation continues as Indonesia is recently ranked $87^{\text {th }}$ out of I27 countries scored 32,42 out of Ioo points (Cornell University, INSEAD, \& WIPO, 20I7). It is essential to note that this score shows a slight improvement this year, even though the trend is still not better than that of the 2014 score.

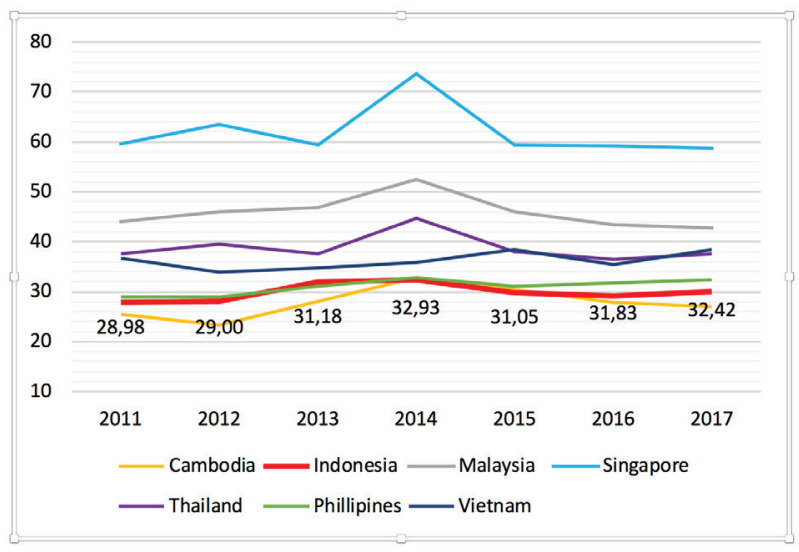

Figure I.I Overall Score of Global Innovation Index for Selected ASEAN Countries in 20II-20I7

Source: author's compilation from Global Innovation Index, 20II-20I7.

The 2014 score of Indonesia's innovation is required a closer examination because it was the most satisfying year in Gll's version of innovation achievement in Indonesia so far. This way is essential to identify what strengths and weaknesses that Indonesia's innovation capacity has. In the 2014 Index, the indicators have been shown that Indonesia had been prominent in intangible assets (ICT and business/organizational model creation), computer software spending to make knowledge impact, and university/industry research collaboration 
in innovation linkage. Whereas, the striking weaknesses of innovation derived from knowledge workers, scientific \& technical articles in knowledge creation, regulatory environment, and institutions (Cornell University, INSEAD, \& WIPO, 20I4, p. I98). Such a situation seems not to change much in 2017 since the recent GII has already demonstrated similar slight conditions (Cornell University et al., 20I7).

The weak capacity of Indonesia's innovation reflects a complex problem in technological development. The government's budget on R\&D was meager, in which Indonesia spent approximately US $\$ 490$ million (o.08 percent) of its US\$ 586 billion in 2009 (Shetty, Akil, Fizzanty, \& Simamora, 20I4, p. 4I). Such an amount of public spending was minimal and far below the R\&D expenditure of other emerging economies. While Indonesia's Gross Domestic Expenditure on R\&D (GERD) only accounted for 0.09 percent in 2012, some countries spent much higher percentage of its GDP on R\&D activities at the same year, such as Japan and Korea (3,4 percent), Singapore (2,2 percent), China ( $\mathrm{I}, 6$ percent), Brazil ( $\mathrm{I}, 3$ percent), Malaysia (I,o percent), South Africa $(0,9$ percent) and India (o,8 percent). Important to note, of those countries, only Indonesia has not changed its constant low spending on $R \& D$ activities (See figure I.2). This stagnated trend corresponded to the view of its Minister of Research Technology and Higher Education, Muhammad Nasir, which stated "national expenditure has increased 4000 times, while R\&D budget only increased 420 times," despite acknowledging a positive correlation between $\mathrm{R} \& \mathrm{D}$ expenditure and innovation outcome (LIPI, 20I6).

Figure 1.2 R\&D expenditure (\% of GDP) for

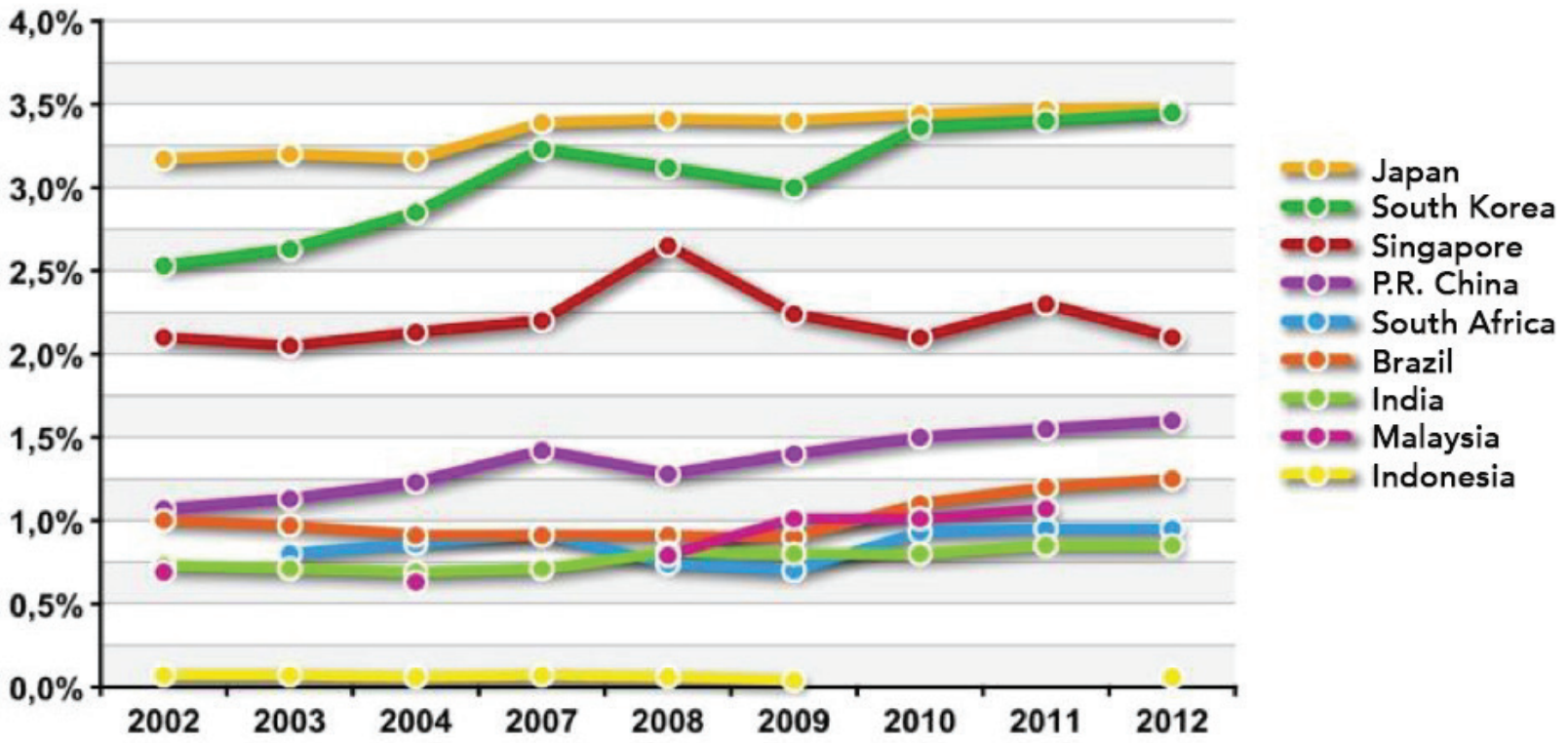

Indonesia and selected countries, 2002-2012

Source: Buku Saku Indikator IPTEK Indonesia (Handayani, 20I4) 
The limited expenditure on R\&D activities corresponds with slow progress in enabling a conducive ecosystem for innovation to grow, particularly in the public sector. For instance, the scientific productivity improvement of Indonesian $R \& D$ actors, namely public universities and research institutes, is meager, and the conduct of research projects has not supported by international collaboration on a research project with foreign researchers or scholars in a sustainable manner. This problem emerged as Indonesian academics remain highly dependent on external parties in producing scientific knowledge and innovation output like international peer-review journals (Lakitan, Hidayat, \& Herlinda, 20I2), patents, and other intellectual properties. In addition, multiple problems in managing complex foreign research permit, ethical clearance, protection of intellectual property rights international collaboration on related subjects involved human-being have remarkably engendered a stagnated innovation in Indonesia and would hamper the national science and technological development in year to come (Rachmawaty, 2017; Shetty et al., 2014).

Limited budget of the government is exacerbated by inappropriate ways of spending and complicated rules regulating the research and development activities in public universities and non-ministerial government agencies. Rather than for the actual research per se, the expenditure tended to be spent for financing routine, administrative, and organizational purposes to supplement their inadequate salary, research incentives shortage, obsolete science and research infrastructures, low travel expanse, and costly capacity-building programs for knowledge workers. Further, limited budget allocation for public research stakeholders is denigrated by excessive bureaucratic and regulatory barriers restricting the research environment to work more flexibly and dynamically. The researchers, as knowledge workers, are regulated in the same way as their fellow government officers in public services and administration are. In other words, researchers have double workloads as both research personnel, and bureaucratic officers without special treatment adjust their profession responsible for creating knowledge, developing science, and generating innovative works for technological development. ${ }^{.}$Such a problem merely leads to over-bureaucratization of the research and knowledge sector, and hence brings about the inconducive environment for competitive innovation.

In contrast, the $R \& D$ expenditure in each sectoral ministry is much higher than that of sectoral research institutes and universities. Frequently their R\&D activities are produced merely a promotional or socialization of the ministries' programs without any contribution to science development. Such ministerial R\&D activities are carried out by non-researcher careers, where they are not charged with researchers' workload and responsibilities but are provided with the more-than-enough expense to conduct few research projects. ${ }^{2}$ These two conditions of R\&D activities in government bodies depicts how complex and problematic the $R \& D$ governance in Indonesia in which its knowledge workers are underappreciated and experiences duties with "More Stick and No Carrot" in producing innovation and technological outcomes. It was undoubted that the massive exodus of highly-skilled researchers and experts is very likely to occur in Indonesia (Taufik, 20I3).

\section{THE CHALLENGES OF INNOVATION AND TECHNOLOGICAL DEVELOPMENT IN INDUSTRIAL SECTOR}

In identifying the challenges, it is crucial to follow the concept of Kian Wie Thee (2006) on the conditions influencing industrial-technological development as a means of industrial competitiveness enhancement. Basic conditions consist of the pursuit of sound macroeconomic policies, the pursuit of pro-competition economic policies, upgrading of human resources while enabling condition involves improving access to foreign technologies, improving the availability of finance, improving the effectiveness and performance of technology support services. Be-

Interview information, 27 March 2017 Interview information, 28 March 2017 
sides, other possible measures are also provided, which are public funding and tax credits for R \& $D$ expenditures, including strategic enterprises, coordination of enterprises in clusters, and explicit Industrial policy. This paper analyzed the most relevant variables to the research problems. Based on careful understanding, five critical aspects need to be elaborated. Those are the R\&D ecosystem, industry-driven innovation, knowledgeable human capital, access to external technologies, and selective industrial policy.

\section{R\&D Ecosystem}

The low R\&D expenditure exposed the limited capacity of Indonesia to provide a conducive ecosystem in supporting innovation to develop dynamically in terms of financial and regulatory facilities. Besides, reforming R\&D governance, the form of government supports enhancing innovation capacity is to provide regulation in strengthening the robust banking system in appraising investment or channeling the right way to invest in innovation and technological development in potential areas. The availability and access in financing innovation are a vital element in allowing an investment in technological innovation sourced from both public funding ( $R \& D$ expenditure) and private finance (bank credits). However, investment in technological upgrading was rarely found even before the I997 crisis. Indonesian banks and non-financial institutions have preferred to channel their loans to private consumption such as housing and credit card, rather than to finance activities related to innovation and technological development due to their high-risks characteristic. Bad experiences cause it during the crisis as corporate borrowers defaulted their loans (Thee, 2006).

In terms of public financial support for innovation, the government of Indonesia has already included technological development as part of its development agenda in late I990. Since then, there have been various government programs in forms of incentives aiming to stimulate $R \& D$ activities, specifically in science and technology areas. However, according to the Indonesian Institute of Sciences renown as LIPI, there were 22 incentive programs with five categories of research throughout the I990s to 2005, yet government agencies and formal bodies had operated all of the activities. The state-controlled and dominated everything related to $R \& D$, either source of funds or the conducts and implementation of the activities, according to Negara, Racine, Chen, and Kay (2013).

The share of government in financing $\mathrm{R} \& \mathrm{D}$ was increasing in some years, while other parties were gradually declining, a typical pattern also appears in the locus of R\&D activities. This trend is considered an unusual way applied in other countries like OECD in which the business sector plays a dominant role in $\mathrm{R} \& \mathrm{D}$ activities. The private sector constituted 70 percent of all R\&D projects. The document reports that the level of government funds in 2009 was higher than in several neighboring developing countries. For instance, in China, the proportion of the Chinese government was only 23,5 percent, and business 7I,I percent financing R\&D. Meanwhile, the activities conducted by the government was only I8,2 percent and 73,2 percent to the non-state actor, such as various community-based and technology-specific development program (Negara et al., 2013).

The state-centric approach, substantially distinct from many countries, seems a factor restricting the involvement of the private sector in improving innovation through productive $\mathrm{R} \& \mathrm{D}$ activities in Indonesia. This reality is problematic as inclusive or non-state-centric financing innovation activities is an essential way to drive technological upgrading (Talalay, Farrands, \& Tooze, I997) through which innovative outcome can bring about a new source of opportunities in productive sectors to be potentially commercialized through creative combination between existing and new technologies or high-tech products, including its refrainment, improvement, and invention in solving multidimensional problems.

\section{Industry-driven Innovation}

The adoption of a state-centric approach in innovation leads to an inability to set up 
effective linkage with private industries. In the past, technological efforts were mostly performed by state-owned enterprises (SOEs) and foreign firms excluding private-sector or university involvements, where the conduct of technology transfer and R\&D activities were dominated by public institutions (Aroef, Djamal, \& Ilwan, 2009). The impact generated is apparent in public $\mathrm{R} \& \mathrm{D}$ that characterized by supply-driven (researchers determines the research) than demand-driven research (relevant end-users determine research). Public research institutes have little awareness of the actual needs of industries. Likewise, private industries have little knowledge of the availability of research institute outcomes or even no confidence with the ability of the researcher in the public institutions to provide innovation and technological assistance for industrial needs. This propensity, consequently, has not been able to shape strong academia-industries linkage effectively (Thee, 2006), which partly explained why many leading foreign-capital companies are more interested in establishing innovation centers or R\&D facilities in other Southeast Asia countries than in Indonesia.

In this regard, the private industry operated in Indonesia has little interest to involve and limited capacity to perform in innovation activities, especially in the manufacturing sector. The general picture of innovation in Indonesia's manufacturing sector is provided by Wijayanti and Nadhiroh (2012) in their firm-level survey involving 1223 respondents. The survey found out that low-technology firms with $20-99$ workers and averages annual sales less than \$ 3750 dominated the manufacturing industry that constitutes around $79 \%$. These firms have conducted mainly innovation in forms of marketing innovation $(69,8 \mathrm{I} \%)$, product innovation $(62,26 \%)$, process innovation $(54,99 \%)$, and organizational innovation (5I,62\%), while innovation activities have been dominated by market introduction of products innovation $(85.70 \%)$ and after-sale services $(78.07 \%)$ - the trend above related to low-quality human resources working on manufacturing firms. The majority of their labor forces have secondary education as the highest of education level
(80\%), and hence there are few workers able to allocate to R\&D activities, which only contribute $15 \%$ of marketing employees. Such findings showed how marketing innovation benefiting close relations to consumers is much preferable than product and process innovation, rewarding parts for product competitiveness.

Furthermore, more than $90 \%$ of firms tend to undertake innovation activities independently without any cooperation with other firms and institutions. The ratio of domestic firms conducting innovation is relatively smaller than those of foreign-owned and joint venture firms. There are only i2 \% of firms willing to cooperate for conducting innovation. The majority of manufacturing firms signify that the purpose of the cooperation is merely ways of acquiring new market access (7I,II\%) and new distribution channels (70\%), rather than for improving the durability and quality of products, and for speeding up production capacity. The majority of these manufacturing firms still rely on a source of innovative ideas on both external information of customers and internal information of staff in various divisions. This overview shows how the firms still envisage several problems in promoting innovation, such as lack of internal budget to finance high risk and costly R\&D. Manufacturing firms allocate around $1 \%-23 \%$ of their expenditure for $R \& D$ activities depending on the scale of the business by labor force and turnover. Meanwhile, the source of financing generally derives from less than $3 \%$ of the government's public funds and financial institutions, namely banks, venture capital, and others. The larger the scale of business a firm has, the higher the allocation for innovation is (Wijayanti \& Nadhiroh, 20I2).

The academia-industry linkage is very crucial to assist private industry and stakeholders in enhancing their competitiveness and productivity, specifically Small and Medium Enterprises (SMEs). The enterprises usually have a lack of information about research outcome and meager R\&D capacity. This gap actually can be fulfilled with a more proactive role of public research institute based on government political will to drive SMEs' productivity and performance-based innova- 
tion. Otherwise, the industry will continue to operate its old-fashioned way to compete in the international market (Thee, 2006). Therefore, it can be said that these aggregated weaknesses are a fundamental deficiency of the innovation system in Indonesia's industrial sector.

\section{Human Capital in the Knowledge Sector}

The availability of high-quality human resources is imperative technological capabilities of industries since it determines the degree of domestic absorptive capacity of Indonesia. Absorptive capacity refers to "a wide range of capacities, from the most basic skills in reading, writing, and mathematics to scientific and other advanced capabilities" (Isaksson, 2007) that are equipped to the domestic labor force in performing its work much more effectively. Sufficient of the capacity would allow Indonesian firms to adopt imported advanced technologies of technology frontiers to local conditions. Subsequently, it will enable them to such adoption into manufacturing products with high local content (Eichengreen et al., 2013). The main objective of such a mechanism is to acquire the ability to move up their technological level and the capacity to embody advanced technologies to Indonesian export products.

However, the condition of human resources in innovation remains uncompetitive due to inadequate scientific output, irresponsive higher-education system, lack of capacity knowledge workers, and the brain-drain of skilled workers phenomena (Taufik, 2013). Based on SClmago Country Rank in 2014, Indonesia was ranked $50^{\text {th }}$ of 23 I countries in an academic publication, which produced 6760 documents with H-Index score 2I4 (equal to 6.33 citation per documents). This achievement was a notable increase compared with the 2orI's rank placing Indonesia in $56^{\text {th }}$ of 228 countries with 3474 documents and $\mathrm{ro.8I}$ in citation ratio per documents in the same $\mathrm{H}$-Index score. The increasing number did not satisfy enough with other emerging economies, like Malaysia, Singapore, Thailand, India, China, South Korea, Turkey, and Brazil (SCImago Journal Rank, 20I4).
In terms of human capital investment, Indonesia has strongly committed support in the education sector for catching up on the level of its fellow countries. Such effort has been strived through increasing budget allocation at least 20 percent of total GDP, improving access, infrastructure, and equal opportunities for all citizens to education. However, the rise of education expenditure has a negative correlation with education quality and students' performance by which access to middle-high and higher education remain low measured by international standards, particularly for students from low-income families. Such quality of education has been lagging, or in critical condition as the cognitive skill of Indonesia, students are performed poorly and even shown decelerating trends, especially in Mathematics and Science, compared to other developing countries (Cerdan-Infantes, Makarova, AlSamarrai, \& Chen, 2013).

Likewise, the school enrollment ratio of Indonesia constituted 83,55 percent for secondary education, and 29,56 percent for tertiary education (World Bank, 20I4b, 20I4c). Secondary education d inadequately develops competence in basic literacy, numeracy, critical thinking, and creative skills, as well as remains heavily dependent on rote learning. As a result, high school graduates do not equip with required capabilities for a more complex and diversified manufacturing sector through which they would unable to benefit from on-the-job training (Thee, 2006).

Moreover, the higher education system in Indonesia is not responsive enough to the country's labor market. Many companies tend to perceive the skills of current Indonesia's labor force is a significant constraint to their businesses. According to the World Bank (20I4d), the industrial sector received the smallest portion of the higher-education graduates. For instance, the manufacturing sector only obtained 7 percent of highly skilled graduates in the total workforce available. Such a trend indicates how the higher education sector in Indonesia is not able to provide an adequate talent pool with a potential and adequately 
skilled workforce to the industrial sector in general and the knowledge sector in particular.

As a consequence, such typical findings above have led to the existence of incongruity between human resources supply and industrial labor demand, including between skills learned (in school, university, vocational school, and training centers) and skills demanded by industries. In addition to mismatches, vocational schools in Indonesia are still being perceived as second-class school education to high-school (SMA) due to unabsorbed alumni in industrial jobs, which available teachers in the schools are sometimes not qualified enough to train the students based on labor market demand. This reality has hindered the developing a process to create a high-quality workforce for improving the capacity of firms to produce value-added outputs. In considering findings as such, World Bank's study concludes that the higher-education system in Indonesia is currently unresponsive to labor market dynamics (World Bank, 20I4d).

\section{Access to External Technologies}

Following the lack of absorptive capacity, another problem inhibiting technological innovation development of Indonesia's manufacturing industries is an ineffective use of channels for improving access to foreign technologies. The access mainly consists of technology and knowledge transfers from global or multinationals to local industries, which are learning and absorbing processes new technologies of more advanced countries. As a net technology importer, the unimpeded transfer of technology is essential to raise Indonesia's economic productivity and competitiveness. In so doing, Indonesia has utilized various channels of international technology transfers, which principally comprise of foreign direct investment (FDI), technical licensing agreements, import of capital goods, and technical assistance by foreign partners (Okamoto \& Sjöholm, 20oI; Thee, 2006).

However, international technology transfer has brought about limited or even a lack of benefits for the technological capabilities of manufacturing industries. The limitation was pronounced when we refer data on the flow of foreign capital in Indonesia over its high-tech export. As revealed by the Indonesia Investment Coordinating Board/BKPM (20I4), there was a remarkable rise in foreign investment in the manufacturing sector during the 2010-20I4 period. The capital rise accounted for 20,6 percent in 2010 and consistently increased by 55,4 percent in 2013. In the same period, the trend is inversely proportional to the rate of high-tech exports of manufactured exports that declined from 9,7 percent in 2010 to 7,o percent in 2013. This negative correlation between FDI and high-tech exports steadily continued in the following year as the foreign capital in the manufacturing sector constituted 50,9 percent, while high-technology exports had only 6,9 percent (BKPM, 20I4; World Bank, 20I7b).

According to Thee Kian Wie's (2005) research, the transfer through FDI projects only develop necessary production capabilities and sporadically adaptive capabilities, useful for employees to adjust imported technologies to local condition. Such FDI schemes do not allow local workers to develop those skills further, mainly involved in costly R\&D activities. Aside from inconducive environment to develop innovation and technological capabilities, foreign firms perceive that it is uneconomical to set up R\&D facilities in Indonesia because of its relatively small scale of the domestic market. The limited advantages for technological capabilities to Indonesia manufacturing are also the cases in other channels of international technology transfer, namely technical licensing agreements restricting innovative capabilities of domestic firms, capital goods import demanding high-skills employees, and foreign clients-led technical assistance curbing local firms' marketing or investment capabilities. As a result, lack of adaptive and highly skilled labor forces has caused Indonesia's firms unable to utilize imitatively reverse engineering of foreign technologies as a significant channel of technology transfer as performed in the successful experience of Korea's industrialization. 
On a closer look, this problem is related to inappropriate operationalization of the technology transfer concept in Indonesia, which adopts B.J. Habibie's well-known postulation "begins at the end and ends at the beginning." His ideas concern the distinctive feature of advanced economies' technology cycle from developing economies like Indonesia. While the former undergoes four stages starting from research, development, design, and production, the latter goes through in the opposite direction that begins with production, design, development, and research (Shetty et al., 20I4). To date, Indonesia has already done well in production and design stages owing to the adequate and creative workforce. However, the technology cycle has been stuck at stages of research and development or $\mathrm{R} \& \mathrm{D}$ due to limited adaptative and innovative capabilities of available labor in developing imported technologies to the local context, as well as the inconducive environment, as shown earlier.

To achieve a more active international transfer of technology, Indonesia has to concern about building a talent pool and bureaucratic reform more seriously. The shortage of highquality labor force is a fundamental problem in hindering technological development, specifically in the industrial sector, given human capital, innovation, and technological capabilities components constitute a mutual interconnection and interdependence among each other to ensure such technological cycle work properly. Once one component is not enacted inappropriate way, it would engender such a vicious cycle of technological stagnation through which technological capability will hardly make remarkable progress to catch up technology frontiers - in addition, making sure that ease of doing technological innovation through removing unnecessary bureaucratic rules in related areas in place is important for Indonesia to substantiate such effort.

\section{Selective Industrial Policy}

Optimization of innovation and technological development through $R \& D$ and human capital investments is fundamentally driven by an institution, which can provide incentives for stimulating good government or political stability and a conducive ecosystem. In the context of re-industrialization, the government of Indonesia (GOI) established institutional setting by the adoption of national industrial policy in accelerating industrial development and international competitiveness, namely the Presidential Regulation 28/2008 on National Industrial Policy and the Master Plan for Acceleration and Expansion of Indonesia Economic Development (MP3EI). The former emphasized the promotion of export-oriented industries, specifically agro-based, transportation, and information technology and telecommunication equipment industries, while the latter focused on regulatory reform and implementation of economic corridor strategy in facilitating industrialization across I5 subsectors, strengthening national connectivity, and improving human capital and R\&D investment. Both policies emphasize the development of human resources, innovation, and technological capabilities as a necessary prerequisite for increasing global competitiveness and the contribution of the industrial sector to national (Tijaja \& Faisal, 20I4; World Bank, 20I4a).

In the implementation of those policies, there are a set of policy instruments used by the GOI that comprises of a tariff, non-tariff measures, and tax facilities. These instruments have been designated to establish barriers with purposes of both protecting the latent domestic industry from import competition and facilitating upgrading support for the industrial sector that prioritize export. Since 2007, the GOI has actively imposed tariff policy, including export taxes, to a range of goods that directly contend locally manufactured products. Meanwhile, non-tariff measures are used to restrict importation and to strengthen domestic industry capacity, especially smallholders based on international standards. This restriction is followed by the new industrial bill encouraging the GOI to enforce local content requirements for selected industries as a way of promoting local products use and maximizing local products in government procurement. Further, the GOI has provided tax facilities like tax redemption and reduction in bolstering industrial upgrading for pioneer industries deemed eligible to 
advance higher and strategic value-added, new technological capability, and broader global networks (Tijaja \& Faisal, 20I4).

However, those policy instruments tend to offer protectionist and selective measures in the promotion of domestic firms, while do not provide sufficient measures in the development of innovation and technological capabilities for industries. These are obvious because of the policies merely provided financial incentives or subsidies and a list of national champions as ways of encouraging technological upgrading and globally industrial competitiveness through maximization of natural resource benefits, as mandated by new Industrial Bill 3/20I4. However, policy instruments failed to consider the importance of a conducive ecosystem and more considerable investments for innovation and entrepreneurship in boosting technological capabilities and performance of the industrial sector, problematic after AFC (Naudé, 2013; Tijaja \& Faisal, 20I4).

Further, the purpose of measures involving resource exploitation by industries would cause contradict objectives in improving effort of Indonesia's technology capabilities, as long as there is a remaining propensity that policymakers to pick natural resources, shortterm and faster profit creation, over innovation investment, uncertain and high-risk matters, in industrial development agenda. This indication is apparent as the measures remain targeting existing industries rather than pioneer or new and latent industries, which recently shown some promising and prospective development for the national industry and economy (Tijaja \& Faisal, 20I4), namely the digital economy or e-commerce. In addition to this, the offered measures have also neglected the new dynamic of the global economy and industrial revolution that transform the very nature of manufacturing and production processes wherein the combination of innovation and new technologies are at the core of industrialization (Schwab, 2016).

Given some issues, thus, these protectionist instruments imply that the post-Soeharto GOI has not been moving on to employ the "orthodox" approach in the formulation and implementation of current industrial policy, as used in Orde-Baru era (Margiansyah, 20I7). The incongruence between policy objectives and modes of implementation on industrial technology development partly explains why the government was unable to improve poor performance on innovation and to advance limited technological capabilities of Indonesia's industries as elaborated earlier. Notwithstanding the questionable effectiveness of the policy, the rhetoric of technological innovation development continuously reverberates as a new direction of its industrial aspiring goals in the contemporary public sphere.

\section{INSTITUTION MATTERS: THE ROLE OF STATE IN INDUSTRIAL POLICY}

Given the complex problems that have impeded technological development, this section aims to make political analysis on the role of the post-authoritarian state in governing the technology-based industrial sector as a means of re-industrialization. As discussed in previous part, it is crucial to do since institutions as soft infrastructure affect not merely the success and failure of innovation and technological upgrading in Indonesia (Okamoto \& Sjöholm, 200I), but also determines political outcomes by altering the expectation and behavior of individuals who are as either utility maximizer or satisficers (Hall \& Taylor, I996). To capture political dynamics behind the industrial policy, however, it is required to define it beyond the traditional approach as the government pursued, such as tax facilities or subsidies, but as Dani Rodrik (2004) suggested.

Considering the right institutional setting is crucial, the selective industrial policy in Indonesia has shown how policy architecture is far from ideal and tends to benefit particular strategic industries subjectively deemed pioneer and new activities. This limitation is obvious when only a few companies operated in Indonesia eligible to enjoy a tax holiday facility after the government's approval; those are Unilever and Chandra Asri Petrochemical (kontan.co.id, 2013). This case shows how selective industrial policy only concerns on the amount of capital 
committed by those companies to be invested in the country, while issues relate the contribution to R\&D facilities, (BeritaSatu.com, 2013) innovation and technological development in Indonesia remain disregarded. In typical context, Thee Kian Wie (2006) points out that the introduction of picking-the-winner industrial policy has raised concern as the criteria applied is not very clearly defined and lack of objective consideration for achieving a viable and long-term industrial competitiveness. A broad list of national champions has been perceived that it only encourages particular desires of vested interests and rent-seekers. The selective policy has been suspected of favoring big corporation-owned industries, just like one in the Orde Baru regime, which they only took advantage of subsidies and tax breaks, secured government protection, or assured government procurement without positive prospects for the national economy.

In terms of decision-making, transparency and accountability issues of industrial policy remain questionable since the government, along with political elites and bureaucrats, still become dominant actors in shaping the policy choice. The state actors have insufficiently given concern toward the policy preference of private sectors in such a decision-making process (Rüland, 2016). As stated by the top leader of the Indonesia Chamber of Commerce and Industries (KADIN), the concept of industrialization in Indonesia is a lack of integrativeness in which the tendency of prioritizing sectoral interests is apparent. It is very likely to hinder the realization of converged efforts among public and private actors in strengthening industrial development. Concerning this, KADIN views that the weaknesses of Indonesia's structure of the industry are lack of managerial capacity, debt-dependent financing, reliance on import, weak human resources, and stagnated R\&D activities (Investor Daily, 2013).

For KADIN, this problem should be addressed by the government in industrial development concept, rather than promoting export-orientation industries in the policy. KADIN perceived that such industrial regulation needs to be changed into technology- driven industrialization to increase industrial value-added, specifically in resource-intensive industries (BeritaSatu.com, 2013). Moreover, the fundamental disagreement between the two also occurred in the case of ASEAN economic integration. The member of KADIN, the Indonesian Employers Association (APINDO), doubted that government decision to accept 2003 AFTA and 2010 ACFTA would harm large segments of the private sector, MSMEs in particular (See: Rüland, 20I6). Although KADIN is not a monolithic actor with single interests, those contrasting view between the GOI and KADIN has demonstrated how the state has mostly neglected the participation, preference, and experienced problems of the private sector in the process of industrial policymaking. If there is private sector involvement, it must be selectively included in the decision-making process.

Likewise, in the policy implementation, deficient coordination and synergies among government institutions in central, subnational, and local levels have often obstructed the private sector to perform public-private collaborative works and cooperation optimally. The critical issues regard to the conflicting interests and purpose among stakeholders, both governments and business groups (Rüland, 20I6; Tijaja \& Faisal, 2014). In many experiences, private sectors demand more flexible implementation of complex bureaucracy presumed to decelerate their business processes, while public agencies accentuate on strict enforcement of rules and procedures. The asymmetrical conduct of complicated regulations mostly ended up with uncertainty demotivating private actors to do similar business in typical fields, related explicitly to accelerating efforts of industrial competitiveness. ${ }^{3}$ As a result, the more profound intervention of state bureaucrats as such mostly inhabit effective implementation of industrial policy, which then makes industrial policy prone to entangled in bureaucratic politics and complexity. Notwithstanding the coordinating mechanism is in a place, the reality illustrates how the state has conducted the policy far from

3 Interview information, 27 March 2017 
transparent, publicly legitimate, democratically accountable in providing inclusive interest representation. It ultimately would make effective coordination and strategic public-private collaboration hardly to be achieved.

Based on explication, this paper argues that two ideational factors caused state domination over the formulation and implementation of the industrial policy in the post-Orde Baru era. First, the influence of state corporatism remains influential in shaping the perception of government officials in governing industrial affairs. This idea had been fully-fledged in the authoritarian regime. The state-corporatism refers to the concept representing the institutional relationship between a sound decision-making system and interest representation. The state unilaterally determines who is included and able to participate in implementing policies in selective ways based on the state's goals (Lee, 20I6; Schmitter, I974).

As we know, the government still provide channels of interest representation in accommodating stakeholders' voice-based on the state-corporatist mode of participation, despite mostly private business interests converged in the industrial sector. In the concept of state-corporatism, participation is limited to a top-down approach that only involves "participation in implementation" and "participation in benefits" of the policy, while "participation in decision-making" and "participation in evaluation," typical for liberal-pluralist systems, are very little to recognize. Such mode of participation consequently tends to be used by the government for disseminating information, rather than for openly exchanging views on the policy among stakeholders (Rüland, 20I4b, 20I6). In so doing, the selective industrial policy has arisen a legitimacy question on stakeholders' aspirations due to limited involvement and consensus of the private sector in the policy process.

Moreover, ineffective policy implementation has been caused by the influence of state-corporatism in governmental practice. Such influence generally persists in current institutional order, mainly bureaucracy, since many government officials get used to with static and orthodox views prioritizing the state-as-people interests based on the doctrine of Orde-Baru collectivist ideology. Before Reformasi, state bureaucrats and politicians had politically socialized and internalized state-corporatist ideas as a daily culture of works in the government. As a consequence of thirty-two years of Suharto's reign, the state-corporatist idea deeply entrenched in the collective memory of bureaucrats and political elite in Indonesia. Such a condition remains intact under a democratic setting as the wake of democratization merely transformed the political system and not necessarily an authoritarian culture of bureaucracy (Rüland, 20I4a, 20I6). This tendency undoubtedly hinders intensive coordination between government and business actors as long as state officials keep intervening private sector's efficient and innovative ways of works deemed incompatible to bureaucratic understanding and broadly "business-as-usual" policy. At the same time, such inclination discloses that Indonesia's democratic reform has wholly eliminated a remnant of Orde Baru legacy, state corporatism.

Second, political leaders and government officials have not shown political will and a strong commitment to building an integrative system of science, technology, and innovation in industrial policy. When it comes to talking about technology for economic development, the authoritative state actors and elites, such as the president, realizes the importance and advantageous effect of innovation and technological development for industrialization and its existing problems (BPPT, 20II; LIPI, 2007; Republika, 2012). Notwithstanding giving a supportive impression, such an attitude tends to exhibit only a rhetorical action that evokes optimism and even the political trust of more full societies to achieve the technological vision. However, the strategy and policy instruments offered to embody such technological vision explicitly diverged and incompatible with the spirit constructed to the public, which the policy inclined to focus on market demand, as shown in the selective industrial policy. Even though the government had established the 
national system of innovation (Kompas.com, 20Io), it remains unclear how it is connected to industrial policy comprehensively (Lakitan, 20II).

The absence of a strong commitment to technological development as such is shaped by the historical trajectory of industrialization during the Suharto era. Learning from successful industrialization in South Korea under President Park, the government implicitly guaranteed and encouraged business group (chaebol) to invest "desirable" activities that can boost national industries based on innovation and technology. Such political will and commitment of top leaders resulted in one of the world's leading companies from the country, Hyundai (Basri \& Putra, 2016). In contrast, rapid industrialization in Indonesia under the Suharto regime in I974-I98I had very much relied on the bonanza of the oil boom as the engine of growth, which consequently facilitated the government to adopt importsubstitution strategy fueled with nationalist rhetoric. During this period, Indonesia had not interested to develop technological capability in the industrial sector. ${ }^{4}$

Such a lack of political will to invest in technological development had ever disappeared for a while when B.J Habibie spearheaded the development of the national aircraft industry. The endorsement of Suharto on the N250 project paved the way for Industri Pesawat Terbang Nusantara (IPTN) to prove the world that Indonesia has a vast capacity to build its technological artifacts through the first flight of N250 Gatotkaca in IO $^{\text {th }}$ August 1995, commemorated as National Technological Awakening Day nowadays. The historic moment did not only evoke technological nationalism tremendously encouraging national unity, pride, and public trust to political elites in determining technological action (Amir, 2007). The public enthusiasm on indigenous technology of the regime's high-tech vision had ever brought up optimism that the rise of Indonesia's high-technology industries would be the basis of national development.

4 Interview information, 9 April 2017
Such technological nationalism lasted until the economy and technological state severely devastated by the crisis $1997 / 8$. The crisis forced the succeeding government (anti-Suharto) to shut down existing high-technological projects, and state-coordinated strategic industries management inherited from the Suharto regime (Amir, 20I2). As a consequence, the post-crisis industrialization has heavily relied on primary export and household consumption as the engine of growth following the shifting focus of government to opt primary commodities and extractive industries as main sources of industrial competitiveness (Margiansyah, 20I7). The focus on natural resources and extractive industries is restoring the Orde-Baru concept of selective industrial policy in which the implementation was backed up by military power, state bureaucrats, and the Indo-Chinese business group, as well as provided practices of rent-seeking and corruption exclusively around the regime's crony (Gellert, 20Io).

The absence of political will to technological development is deeply embedded in political elites and government officials who are predominantly subjected to so-called "technological inferiority." The term can be understood as a lack of self-esteem and confidence toward the state of national technological development in one's subconscious mind, due to the extremely advanced technological capabilities of other nations. This feeling would be intensified when he/she realizes that the current state of technology in his/her own nation lagging far behind the others, as well as his/her nation's technological effort, often failed or inadequate. Technological inferiority involves negative perception toward the existing capacity of national technology, unsupportive masses, weak institution, and economic vulnerability.

Such an issue is observable in the notion of "Habibienomics" vis-à-vis "Widjojonomics" as the concept of economic development, which the former stands for competitive advantage based on human capital (including innovation and technology) and the following comparative advantage based on natural resources (Amir, 20I2). The inferiority affects the way of government perception through which state officials 
prioritize policy direction toward primary and low value-added exports over on innovation and technological investment in formulating industrial policy. The rationalization of government officials mostly revolves around the idea that export-orientation bringing short-term growth and profit for the national economy while developing technology capabilities for industries is expensive, high-risk, and likely to be wasteful spending. In this regard, political leaders and bureaucrats, who are associated with utility maximizers devoting to the concept "Widjojonomics," tend to overlook the critical and urgency of innovation and technological capabilities in industrial development. The concerned state actors have obviously dominated decision-making and formulating Indonesia's selective industrial policy, as discussed before.

Important to note that the argument above does not intend to disregard the critical contribution of Professor Widjojo Nitisasro as the modern architect of concept on Indonesia's national development. Notably, his historic role in designing the Sekolah Dasar INPRES program that provided a low-income family to access education in a rural area. The government initiative per se aimed to increase the quality of education and human capital by constructing a large number quantity of (primary) school buildings throughout the nation. According to the research of Esther Duflo (I999), this unusual policy experiment generated beneficial impacts in increasing educational attainment and wages by 8.8-I2 percent. Despite consuming a long time, the positive return was successfully gained to drive rapid economic growth for Indonesia in I970-I990s. Regardless of this successful program, however, the relevance of the "widjojonomics" idea, as aforementioned in encountering the current trend of the globalized economy and technological revolution, must critically be questioned.

Therefore, it can be said that the role of the post-authoritarian state predominantly intervened the policy implementation based on its own interests while neglected a large part of other private stakeholders. The dominant behavior has diverged the very purpose of Industrial policy per se, as a process of eliciting information to achieve the right institutional setting. Instead, the effect of state domination has restored the authoritarian type of industrial policy as in the Orde Baru regime in which it favors vested interests and "crony" of the ruling power. This problem has not simply been caused by the problematic concept of industrial policy and its instruments, but rather the action of the state and political actors retaining the state-corporatist practice in the policy implementation and technologically inferior attitudes in the policy formulation. The two factors associated with Orde-Baru legacy engendered the selective industrial policy performed in the effort of re-industrialization, and eventually led Indonesia's industries to the failure of innovation and technological upgrading.

\section{CONCLUSION}

The paper attempted to examine factors impeding innovation and technological development in manufacturing industries. In the elaboration on current conditions, it has been depicted that Indonesia's innovation capacity is weak, and either public or private actors poorly perform $\mathrm{R} \& \mathrm{D}$ activities. The assessment had identified the weakness aspects of the country's innovation capacity derived from knowledge workers, knowledge creation represented by the production of scientific \& technical articles, regulatory environment, and institutional setting. The lack of commitment from the government to give enormous support to technological efforts in forms of funding, empowering regulation, and competitive environment have become the cause of limited capacity and poor performance in innovation activities.

Moreover, it has highlighted five relevant aspects of challenging capabilities upgrading of Indonesia's innovation and technology in industries, based on Thee Kian Wie's concept. First, lack of supports and over-bureaucratization of $R \& D$ activities generated inconducive ecosystem to develop innovation capacity. Second, the involvement of industries operated in Indonesia in $R \& D$ activities is relatively low in driving Indonesia's innovation activities due to a state-centric approach and weak academia- 
industry linkage. Third, uncompetitive human capital in innovation has created the weak absorption capacity to develop indigenous technology as the knowledge sector has not generated poor scientific output, irresponsive higher-education system, and prevention of brain-drain knowledge workers. Fourth, a vicious cycle of technological stagnation leads to ineffective use of channels for improving access to foreign technologies. Fifth, the selective industrial policy has induced unsuccessful efforts in improving the poor performance of industries based on innovation capabilities.

In the context of re-industrialization, the state has played its role in organizing industrial policy with protectionist measures and selective focus on policy outcome. Such action created problematic effects for private sector aspiration and role in re-industrialization. The implication of the detrimental effects is the obstruction to industrial policy to achieve the right institutional settings that would allow innovation and technological upgrading that occurred in the industrial sector.

Obstructed the right institutional settings of industrial policy hard to achieve, through which it allows innovation and technological upgrading that occurred in the industrial sector. The failure to establish appropriate institutions has perpetuated state domination over a whole policy process and generated ineffective conduct. This issue is caused by ideational factors that affect the perception and attitude of the government officials and, eventually, institutional outcomes. Those are the state corporatist system and technological inferiority state actors in the formulation and implementation of the industrial policy.

The combination of challenges to innovation and technological development and the state-centric approach in industrial policy has become the main obstacle to re-industrialization in post-Orde Baru Indonesia. Those barriers have arisen from deficient technological and institutional conditions of the selective industrial policy caused by state domination in every phase of the policy process with inadequate supports and excessive restrictions. In a closer examination, it was the state corporatism and technological inferiority lying at the root of the state-centric approach in industrialization that affects the state officials to formulate and conduct the policy within the Orde-Baru bureaucratic culture and practice. Therefore, it can be said that the limits of industrialization are not merely material (technological) and institutional capacities of the state, but rather an ideational condition influencing state officials and political elites to prevent profound change on bureaucracy and institutional order.

\section{REFERENCES}

Amir, S. (2007). Nationalist rhetoric and technological development: The Indonesian aircraft industry in the New Order regime. Technology in Society, 29(3), 283-293. https:// doi.org/Io.IoI6/j.techsoc.2007.04.010

Amir, S. (2012). The Technological State in Indonesia: The Co-constitution of High Technology and Authoritarian Politics. Routledge.

Aroef, M., Djamal, J. S., \& Ilwan, H. (2009). Grand Techno-Economic Strategy: Siasat Memicu Produktivitas Untuk Memenangkan Persaingan Global. PT Mizan Publika.

Aswicahyono, H., Hill, H., \& Narjoko, D. (20I2). Industrialization: Patterns, Issues, and Constraints. In H. Hill, M. E. Khan, \& J. Zhuang (Eds.), Diagnosing the Indonesian Economy (pp. I83-226). https://doi.org/10.7135/ UPO9781843313786.008

Basri, F., \& Putra, G. A. (2016). Escaping the Middle Income Trap in Indonesia: An Analysis of Risks, Remedies and National Characteristics. FES Regional Programme Asia. Retrieved from http://www2.fes-asia.org/escaping-the-middle-income-trap-in-indonesia-an-analysis-ofrisks-remedies-and-national-characteristics/

BeritaSatu.com. (2013, June 24). Integrasi Kebijakan Industri Harus Cepat dan Mengarah pada Kesejahteraan. Retrieved September 24, 2016, from Beritasatu.com website: https:// www.beritasatu.com/ekonomi/I2I482/ integrasi-kebijakan-industri-harus-cepatdan-mengarah-pada-kesejahteraan

BKPM. (20I4). Realisasi Penanaman Modal PMDN PMA Triwulan I Tahun 20I4. Retrieved from Badan Koordinasi Penanaman Modal RI website: https://www.bkpm.go.id/images/ uploads/laporan_berkala/file/Press_Release_ TW_I_20I4_-_ind_-_24_April.pdf 
BPPT. (20II, August). Presiden RI: Kontribusi Inovasi dan Teknologi dalam Pengembangan Kekuatan Ekonomi Nasional [Government]. Retrieved August 26, 2017, from Badan Pengkajian dan Penerapan Teknologi website: https://www.bppt.go.id/layanan-informasipublik/84I-presiden-ri-kontribusi-inovasi-dan-teknologi-dalam-pengembangankekuatan-ekonomi-nasional

Cann, O. (2016, September 27). What is competitiveness? Retrieved August 19, 20I7, from World Economic Forum website: https://www. weforum.org/agenda/20i6/o 9/what-iscompetitiveness/

Cerdan-Infantes, P., Makarova, Y., Al-Samarrai, S., \& Chen, D. (2013). Belanja lebih banyak atau belanja lebih baik: Memperbaiki pembiayaan pendidikan di Indonesia (No. 76404; pp. I-6). Retrieved from The World Bank website: http://documents.worldbank.org/curated/ en/86295I468268525596/Belanja-lebih-banyak-atau-belanja-lebih-baik-memperbaikipembiayaan-pendidikan-di-Indonesia

Chang, H.-J., \& Andreoni, A. (2016). Industrial Policy in A Changing World: Basic Principles, Neglected Issues and New Challenges. Cambridge Journal of Economics, 40.

Cohen, J. M., \& Uphoff, N. T. (I980). Participation's Place in Rural Development: Seeking Clarity Through Specificity. World Development, 8(3), 213-235. https://doi.org/Io.IoI6/0305750X(80)900II-X

Cornell University, INSEAD, \& WIPO. (20I4). The Global Innovation Index 20I4: The Human Factor in Innovation. Ithaca, Fontainebleau, and Geneva.

Cornell University, INSEAD, \& WIPO. (20I7). The Global Innovation Index 20I7: Innovation Feeding the World. Ithaca, Fontainebleau, and Geneva.

Duflo, E. (I999). Essays in empirical development economics (Thesis, Massachusetts Institute of Technology). Retrieved from https://dspace. mit.edu/handle/I72I.I/95I6

Eichengreen, B., Park, D., \& Shin, K. (2013). Growth Slowdowns Redux: New Evidence on the MiddleIncome Trap (Working Paper No. I8673). https://doi.org/I0.3386/wi8673

Felipe, J., Ustav, K., \& Galope, R. (20I4).Middle-Income Transitions: Trap or Myth? Retrieved from Asian Development Bank website: https:// www.adb.org/publications/middle-incometransitions-trap-or-myth
Gellert, P. K. (20I0). Extractive Regimes: Toward a Better Understanding of Indonesian Development. Rural Sociology, 75(I), 28-57. https://doi. org/I0.IIII/j.I549-083I.2009.0000I.X

Hall, P. A., \& Taylor, R. C. R. (I996). Political Science and the Three New Institutionalisms. Political Studies, 936-957.

Handayani, T. (20I4). Buku saku indikator iptek Indonesia 20I4. Lembaga Ilmu Pengetahuan Indonesia.

Im, F. G., \& Rosenblatt, D. (2013). Middle-income traps: A conceptual and empirical survey (No. WPS6594; pp. I-40). Retrieved from The World Bank website: http://documents.worldbank. org/curated/en/969991468339571076/Middleincome-traps-a-conceptual-and-empiricalsurvey

Investor Daily. (2013, June 20). Konsep Industrialisasi Nasional Harus Terintegrasi. investor.id. Retrieved from https://investor.id/archive/ konsep-industrialisasi-nasional-harusterintegrasi

Isaksson, A. (2007, July). Determinants of total factor productivity: A literature review. Retrieved from http://www.unido.org/fileadmin/user_media/Publications/Research_and_statistics/ Branch_publications/Research_and_Policy/ Files/Working_Papers/2007/WPo22007\%20 -\%2oDeterminants\%2oof\%2ototal\%2ofactor\%2oproductivity.pdf

Kompas.com. (2010, January 20). SBY Bentuk Sistem Inovasi Nasional. Retrieved September 26, 20I7, from KOMPAS.com website: https://regional.kompas.com/ $\mathrm{read} / 20$ Io/or/20/2034436I/sby.bentuk.sistem. inovasi.nasional

kontan.co.id. (2013, January I8). Unilever dan Chandra Asri kantongi tax holiday. kontan. co.id. Retrieved from http://nasional.kontan. co.id/news/unilever-dan-chandra-asrikantongi-tax-holiday

Lakitan, B. (20II). Kebijakan Riset dan Inovasi Nasional. Retrieved from https://www.academia. edu/7536399/Kebijakan_Riset_dan_Inovasi_Nasional

Lakitan, B., Hidayat, D., \& Herlinda, S. (20I2). Scientific Productivity And The Collaboration Intensity Of Indonesian Universities And Public R\&D Institutions: Are There Dependencies On Collaborative R\&D With Foreign Institutions? Technology in Society, $34,227-238$. 
Lee, S. S.-Y. (20I6). Institutional legacy of state corporatism in de-industrial labour markets: A comparative study of Japan, South Korea and Taiwan. Socio-Economic Review, I4(I), 73-95. https://doi.org/Io.Io93/ser/mwvo29

LIPI. (2007, July I). Presiden: Iptek belum beri kontribusi positif bagi industri [Government]. Retrieved September 26, 2017, from Lembaga Ilmu Pengetahuan Indonesia website: http://lipi.go.id/berita/single/PresidenIptek-belum-beri-kontribusi-positif-bagiindustri/I70I

LIPI. (2016, September I9). Anggaran Riset Indonesia Terendah Di Asia Tenggara. Retrieved May 6, 20I7, from http://lipi.go.id/berita/ single/ANGGARAN-RISET-INDONESIATERENDAH-DI-ASIA-TENGGARA/I628I

Margiansyah, D. (20I7). Disconnecting Technological Inferiority?: Evaluating State Action on Industrial Technological Development in "Post-Orde Baru” Indonesia (Master Thesis). AlbertLudwigs Universität Freiburg, Freiburg.

Naudé, W. A. (2013). Why Indonesia Needs a More Innovative Industrial Policy. ASEAN Journal of Economics, Management and Accounting, $I, 48-65$.

Negara, S., Racine, J.-L., Chen, D., \& Kay, L. (2013). Indonesia-Research and development financing (No. 746I9; pp. I-72). Retrieved from The World Bank website: http://documents.worldbank.org/curated/en/2746oI468043470302/ Indonesia-Research-and-developmentfinancing

Okamoto, Y., \& Sjöholm, F. (200I). Technology Development in Indonesia. In S. Lall \& S. Urata (Eds.), Competitiveness, FDI and Technological Activity in East Asia. Retrieved from https:// www.elgaronline.com/view/184376II49.xml

Paus, E. (2017). Escaping the Middle-Income Trap: Innovate or Perish. Retrieved from https:// www.adb.org/publications/escaping-middleincome-trap-innovate-or-perish

Rachmawaty, R. (20I7). Ethical Issues In ActionOriented Research In Indonesia. Nursing Ethics, 24(6), 686-693.

Republika. (20I2, September 29). Presiden: Transfer Teknologi Sulit Dilakukan. Retrieved July 26, 2017, from Republika Online website: https://republika.co.id/berita/nasional/ umum/I2/o9/29/mb36xf-presiden-transferteknologi-sulit-dilakukan

Rodrik, D. (2004). Industrial Policy for the TwentyFirst Century (SSRN Scholarly Paper No. ID 6I7544). Retrieved from Social Science Research Network website: https://papers. ssrn.com/abstract=6I7544
Rüland, J. (2014a). Constructing Regionalism Domestically: Local Actors and Foreign Policymaking in Newly Democratized Indonesia. Foreign Policy Analysis, IO(2), I8I-20I. https:// doi.org/Io.IIII/fpa.I2002

Rüland, J. (20I4b). The limits of democratizing interest representation: ASEAN's regional corporatism and normative challenges. European Journal of International Relations, 20(I), 237-26I. https:// doi.org/Io.II77/I354066II2445289

Rüland, J. (20I6). Why (most) Indonesian businesses fear the ASEAN Economic Community: Struggling with Southeast Asia's regional corporatism. Third World Quarterly, 37(6), II30-II45. https://doi.org/Io.Io8o/oI436597 .2015 .1133245

Schmitter, P. C. (I974). Still the Century of Corporatism? The Review of Politics, 36(I), 85-I3I. Retrieved from JSTOR.

Schwab, K. (2016, January I4). The Fourth Industrial Revolution: What It Means and How to Respond. Retrieved September 23, 20I7, from World Economic Forum website: https://www.weforum.org/agenda/20i6/oI/ the-fourth-industrial-revolution-what-itmeans-and-how-to-respond/

SCImago Journal Rank. (20I4). SJR - International Science Ranking. Retrieved August 26, 20I7, from https://www.scimagojr.com/countryrank.php?year=20I4

Shetty, P., Akil, H., Fizzanty, T., \& Simamora, G. (20I4). Indonesia: The atlas of Islamic World Science and Innovation Country Case Study. San Francisco: Creative Commons.

Talalay, M., Farrands, C., \& Tooze, R. (I997). Technology, culture and competitiveness: Change and the world political economy. London; New York: Routledge.

Taufik, T. (20I3, April). An Adjustment Reform towards a more Integrated Innovation System Strengthening Indonesia Cluster Policy Context. Technology. Retrieved from https://www. slideshare.net/tatang.taufik/an-adjustmentreform-towards-a-more-integrated-innovation-system-strengthening-indonesiacluster-policy-context-by-tatang-a-taufik

Thee, K. W. (2005). The Major Channels of International Technology Transfer to Indonesia: An Assessment. Journal of the Asia Pacific Economy, Io(2), 2I4-236. https://doi. org/10.1080/13547860500071493

Thee, K. W. (2006). Technology and Indonesia's Industrial Competitiveness (No. 43). Retrieved from ADB Institute website: https://www.adb.org/ 
publications/technology-and-indonesiasindustrial-competitiveness

Tijaja, J., \& Faisal, M. (2014). Industrial Policy in Indonesia: A Global Value Chain Perspective (Working Paper No. 4II). Asian Development Bank (ADB).

Wijayanti, R., \& Nadhiroh, I. M. (2012). Potret Inovasi Industri Manufaktur 20II. Jakarta: LIPI.

World Bank. (20I4a). Indonesia - Avoiding the Trap: Development Policy Review 2014 (No. 86025; pp. I-I3I). Retrieved from The World Bank website: http://documents.worldbank.org/ curated/en/93648I468042895348/IndonesiaAvoiding-the-trap-development-policyreview-20I4

World Bank. (20I4b). School enrollment, secondary (\% gross)-Indonesia|Data. Retrieved August 3, 2017, from https://data.worldbank.org/ indicator/SE.SEC.ENRR?end=2015\&location $\mathrm{s}=\mathrm{ID} \& \mathrm{star}=\mathrm{I} 988$,

World Bank. (20I4c). School enrollment, tertiary (\% gross)-Indonesia | Data. Retrieved August 3, 20I7, from https://data.worldbank.org/ indicator/SE.TER.ENRR?end=20I7\&locatio $\mathrm{ns}=\mathrm{ID} \& \mathrm{start}=\mathrm{I} 988$

World Bank. (20I4d). Sistem pendidikan tinggi Indonesia:Seberapa responsifterhadap pasar kerja?(No. 89222; pp. I-I2). Retrieved from The World Bank website: http://documents.worldbank. org/curated/en/987731468266684105/Sistempendidikan-tinggi-Indonesia-seberaparesponsif-terhadap-pasar-kerja
World Bank. (20I7a). Exports of goods and services (\% of GDP) - Indonesia| Data. Retrieved May 26, 20I7, from https://data.worldbank.org/ indicator/NE.EXP.GNFS.ZS?locations=ID

World Bank. (20I7b). High-technology exports (\% of manufactured exports)-Indonesia | Data. Retrieved May 26, 2017, from https://data. worldbank.org/indicator/TX.VAL.TECH.MF. ZS?end $=2016$ \&locations $=I D \&$ start $=1989$

World Bank. (20I7c). Manufactures exports (\% of merchandise exports)-Indonesia, Thailand, Malaysia, India, China Data. Retrieved May 26, 2017, from https://data. worldbank.org/indicator/TX.VAL.MANF. ZS.UN?end $=2016$ \&locations $=$ ID-TH-MY-IN$\mathrm{CN} \&$ start $=\mathrm{I} 988$

World Bank. (20I7d). Manufacturing, value added (\% of GDP) - Indonesia| Data. Retrieved May 26, 20I7, from World Bank website: https://data. worldbank.org/indicator/NV.IND.MANF.ZS? end $=2017$ \&locations $=$ ID\&start $=1988$ 